\title{
Career Goals in High School: Do Students Know What it Takes to Reach Them and Does it Matter?
}

\author{
Marc Frenette \\ Social Research and Demonstration Corporation
}

\begin{abstract}
Do students know the level of education required to achieve their career objectives? Is this information related to their education pathways? To address these questions, I compare high school students' perceptions of the level of education they will require for the job they intend to hold at age 30, with the level required according to professional job analysts. About three out of four students intending to work in a job requiring a university degree know the level of education that is required to obtain the job. Moreover, students who know that a university degree is required are more likely to attend university. Finally, higher university attendance rates are observed when students learn earlier (rather than later), that a university degree is required for their intended job.
\end{abstract}

\section{RÉSUMÉ}

Les élèves savent-ils quelles études leur permettront d'atteindre leurs objectifs de carrière? Ces renseignements sont-ils associés à leur parcours scolaire? Afin de répondre à ces questions, je compare, d'une part, la perception qu'ont les élèves du secondaire quant au niveau d'instruction qui leur est requis pour travailler dans la profession qu'ils souhaitent exercer à l'âge de 30 ans avec, d'autre part, le niveau réellement requis selon les analystes du marché professionnel. Ainsi, environ trois étudiants sur quatre ayant l'intention d'exercer une profession qui nécessite un grade universitaire sont conscients du niveau d'instruction requis. Par ailleurs, les élèves qui sont conscients de la nécessité d'un grade universitaire ont plus de chances de fréquenter l'université. Enfin, on observe un taux de fréquentation universitaire plus élevé chez les élèves qui ont pris conscience, plus tôt dans leur parcours, de la nécessité d'un grade universitaire pour réaliser leur aspiration professionnelle. 


\section{INTRODUCTION}

There has been a surge in research over the last decade investigating factors associated with access to university studies in Canada. Several important conclusions can be drawn from this work. First, prior academic performance matters considerably (Frenette, 2007): it is hardly surprising that students who are already high achievers are more likely to pursue more schooling. Moreover, academic performance tends to explain other well-known facts about post-secondary attendance. For example, females are more likely to pursue university than males largely because of higher performance and greater effort in high school (Frenette \& Zeman, 2007). It is also well known that the gap in university attendance between males and females has been rising rapidly over the last two decades. A study by Christofides, Hoy, and Lang (2006) suggests that women are seeing rising economic returns to completing a university degree and this explains most of the evolving gender gap in university participation. Higher academic achievement also plays a large role in understanding why university attendance rates vary by place of birth (Finnie \& Mueller, 2008). Another important factor is parental education, although the causal mechanism is not well understood (Finnie, Sweetman, \& Lascelles, 2005). Frenette (2007) finds that self-reported financial constraints only play a small role in explaining why lower-income youth are less likely to attend university. This does not mean that money is irrelevant since academic performance may itself be a function of family economic resources (e.g. tutoring or cultural activities may be more accessible to well-to-do families). Furthermore, changes in university costs have been shown to alter the composition of the student body along socio-economic strata (Frenette, 2008a). Costs may also matter for students in certain situations, for example, living at a distance from a university (Andres \& Looker, 2001; Frenette, 2004, 2006, 2009).

Despite the volume of studies, none have directly investigated the relationship between knowledge of education requirements and university attendance. Bell and Bezanson (2006) conclude that career development services (broadly defined) can reduce the high school dropout rate, especially for disadvantaged youth. In a controlled social experiment, the Social Research and Demonstration Corporation, in collaboration with the Canada Millennium Scholarship Foundation, are investigating the impact on future educational outcomes by providing high school students with education and labour market information (Currie, Hutchison, Ford, Kwakye, \& Tattrie, 2007).

This article fills the gap in the literature by answering three questions. First, to what extent do student perceptions of educational requirements for their intended career (garnered from survey data) match the requirements according to professional job analysts at Human Resources and Skills Development Canada (HRSDC). I focus on students who intend to work in a job requiring a university degree since these are clearly defined in HRSDC's framework. Second, what factors are correlated with student perceptions of educational requirements? Third, are student perceptions of educational requirements associated with subsequent educational outcomes?

To date, research has not investigated student perceptions of educational requirements for their intended career, either in Canada or the rest of the world. There are studies, including some in Canada, that examine student knowledge of costs and benefits associated with higher education. Specifically, evidence from survey data compiled by Ipsos Reid suggests that Canadians tend to overestimate the cost and underes- 
timate the benefits of a university education and that the estimation errors are larger among low-income Canadians (Usher, 2005). The current article contributes to our understanding of information constraints by assessing the extent to which students are aware of the educational requirement for their intended career, and its relationship with future outcomes.

The article describes first the data and methods used, including the approach adopted to measure students' perceptions of educational requirements for their intended career. The results are presented in the following section. Finally, the results are summarized and placed into policy context in the conclusion.

\section{METHODOLOGY}

The data are drawn from the Youth in Transition Survey (YITS), Cohort A. This survey was developed in conjunction with the Programme for International Student Assessment (PISA), a project of the Organization for Economic Co-operation and Development that consisted of standardized tests in reading, mathematics, and science. The target population consisted of students enrolled in an educational institution on December 31, 1999, who were 15 years old on that day - that is, they were born in 1984. The assessment took place in April or May 2000 (Cycle 1). Furthermore, background questionnaires were administered to students through PISA and YITS. Parents and schools were also administered questionnaires through YITS. Students were followed up every two years thereafter. Currently, data for Cycle 4 are available (when the same students were roughly 21 years old).

Students living in the territories or on Indian reserves, as well as students who were deemed mentally or physically unable to perform in the PISA assessment and those with less than one year of instruction in the language of assessment were excluded. The survey design consisted of a two-stage approach. In the first stage, a stratified sample of schools was selected to ensure adequate coverage in all of the 10 Canadian provinces (including minority school systems in certain provinces). The stratification was based on the enrolment of 15-year-old students in the school in the previous academic year. In the second stage, a simple random sample of 15-year-old students within the school was selected. ${ }^{1}$

Two questions in YITS are used to measure student perceptions of educational requirements for their intended career. The first is:

- "What kind of career or work would you be interested in having when you are about 30 years old? (TeLL US ONE ONLY)."

This question is asked when the student is 15 years old and again when the student is 17 years old. Statistics Canada coded the descriptive text provided by the students into a S0C91 (Standard Occupational Classification - 1991) code. The S0C91 is a four-digit code describing occupations in a hierarchical manner. For example, the first digit describes a very broad occupation. The second digit will describe a sub-category within the broader one digit code. It is common practice to describe occupations using the S0C91 using one, two, three, or four digits, depending on the level of detailed desired by the researcher. Later, in Figure 1 and Table 2, I will classify occupations by one and three digit S0C91 codes, respectively. 
One limitation of the SOC91 code is the lack of information on educational requirements. However, SOC91 easily maps into the NOC (National Occupational Classification), which is a different way of classifying occupations. Importantly, the NOC contains information on educational requirements in its second digit. This information is based on employer interviews conducted by professional job analysts at HRSDC. The second digit ranges from 0 to 6 , which is grouped into the following four skill levels:

Skill level A (Second digit NOC $=1$ ):

- University degree at the bachelors or post-graduate level.

Skill level B (Second digit NOC $=2$ or 3 ):

- Two or three years of post-secondary education at a community college, institute of technology, or Collège d'enseignement general et professionnel (CEGEP); or

- Two to four years of apprenticeship training; or

- Three to four years of secondary school and more than two years of on-the-job training, specialized training courses, or specific work experience; or

- Occupations with supervisory responsibilities and occupations with significant health and safety responsibilities, such as firefighters, police officers, and registered nursing assistants.

Skill level C (Second digit NOC $=4$ or 5):

- One to four years of secondary school education; or

- Up to two years of on-the-job training, specialized training courses or specific work experience.

Skill level D (Second digit NOC $=6$ ):

- One to two years of secondary school and short-work demonstration or onthe-job training.

Note that code 0 is missing from the list above. This corresponds to management occupations, which HRSDC does not classify into a skill level.

Of the four skill levels, only skill level A (a university degree) clearly corresponds to a well-defined education level. For this reason, this article focuses on students who aspire to work in a job that, according to HRSDC, requires a university degree.

As described at http://www5.hrsdc.gc.ca/NOC/\#3, the skill level corresponds to the type and/or amount of training or education typically required to work in a given occupation. Each skill level is intended to reflect commonly accepted paths to employment in an occupation. Where there are several paths to employment, the skill level most commonly identified by employers is used.

The second question used to measure student perceptions of educational requirements for their intended career is:

- "How much education do you think is needed for this type of work? (MARK ALL THAT APPLY.)" 
This question immediately follows the previous one about career intentions. If students give more than one answer, I capture the highest level only. This approach yields a conservative estimate of the proportion of students who believe less education is required than the HRSDC benchmark.

The next step is to create a binary indicator of knowledge of educational requirements. Recall that the sample only includes students who aspire to an occupation that requires a university degree, according to HRSDC. Two alternative definitions are used:

1. Students know the educational requirements for their intended career if they believe a university degree is required: that is, they agree with HRSDC.

2. Students know the educational requirements for their intended career if they believe a post-secondary certificate of some sort is required.

The first definition is the primary one, used throughout most of the article and based on the HRSDC benchmark. The second definition allows for the possibility of heterogeneous requirements across jobs within the same occupational classification wherein, for example, some jobs require a university degree, while others require a college certificate. Recall that HRSDC provides the level of education most commonly required by employers. Some employers may require less education and students might be aware of such employers. The second definition is used mainly as a test of robustness when I investigate the role of knowledge of educational requirements on educational choices. The definition is analogous to the one used by Galarneau and Morissette (2004), in their study of job mismatch among recent immigrants.

The first part of the analysis will examine student perceptions as an outcome. Covariates include sex, academic performance (PISA reading scores, the overall mark in school), birth order, parental background (education, income, immigrant status, presence), and a series of binary variables indicating each school. These variables are described in detail in Frenette (2008b). Descriptive sample statistics of these variables appear in Appendix 1.2

I also estimate the relationship between years of schooling and student perceptions. To do so, I compare students assigned to grades 9 and 10 based on their exact date of birth and the school entry laws. This exercise is only possible in Nova Scotia and Québec since students in those provinces enter the school system based on their age as of October 1 (Nova Scotia) or September 30 (Québec), whereas in most other parts of the country, the cut-off date is December 31. Youth in the sample were all born in 1984, which means that in most provinces, they are assigned to grade 10 in the first cycle of the YITS data, while in Nova Scotia and Québec, some are assigned to grade 10 (those born prior to the cut-off date), while others are assigned to grade 9 (those born later). In the second cycle, I can compare students assigned to grade 11 and 12 in Nova Scotia; however, no such comparison is possible in Québec since students either begin CEGEP or leave the school altogether following grade 11.

To estimate the impact of schooling (separate from general maturation effects due to aging or influences of the parents), I compare students assigned to different school grades, but control for detailed age. See Frenette (2008a) for more details on this approach. ${ }^{3}$ Of course, the drawback of this exercise is that the results are limited to the provinces where such an analysis is possible. Fortunately, this is the only part of the paper where such a limited scope is applied. 
The final step in the analysis is to examine the extent to which knowledge of educational requirements are correlated with future educational outcomes (i.e., highest level attended by age 21). The main outcome examined is university attendance, although results for college attendance, as well as high school completion are also shown.

\section{RESULTS}

Before delving into the main results, it is worthwhile taking a step back to look at the distribution of career aspirations of students. Three occupational distributions are plotted in Figure 1. The first is the distribution of intended occupations by age 30, of 15 -year-old high school students, using the YITS data (sample size $=8,346$ ). Similarly, the second shows the distribution when the same cohort is 17 years old (sample size $=$ 8,354). These distributions are then compared to the actual distribution of occupations among 30-year-olds in the 2001 Census. Recall that most of the analysis to follow focuses on youth who aspire to a job requiring a university degree (according to HRSDC). However, this is not the case in Figure 1. All youth who responded to the question on career aspirations (five in six), are included. The results are aggregated at the first digit of the S0C91 (thus describing very broad occupations).

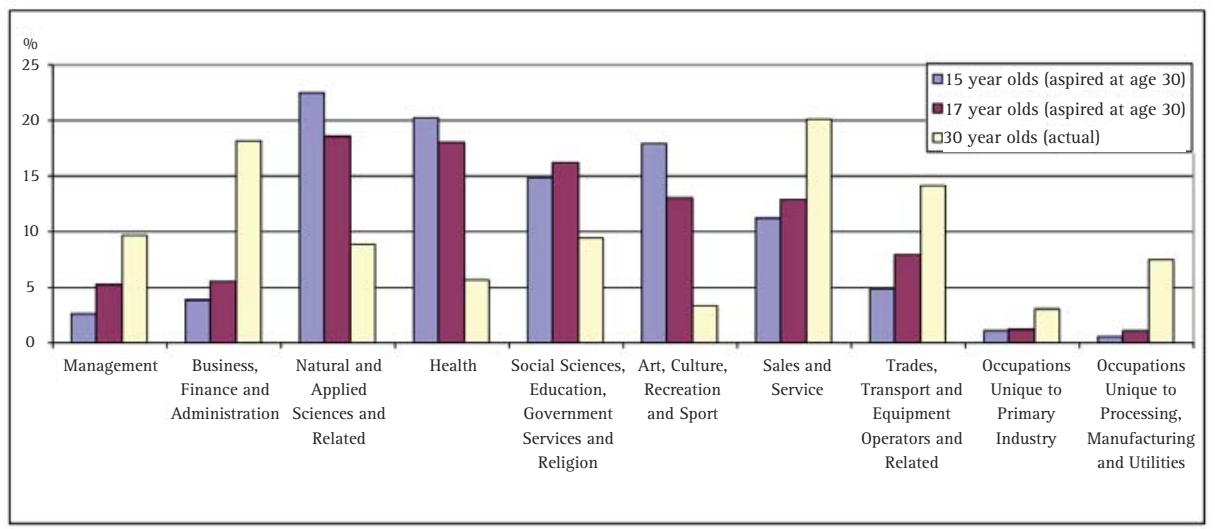

Sources: Youth in Transition Survey (YITS), Cycle 1 and 2; Census, 2001

Figure 1: Percent distribution of occupations

The results suggest that youth aspirations differ from the actual distribution of occupations in the economy. In particular, youth are more likely to aspire to work in occupations such as natural and applied sciences and related; health, social sciences, education, government services, and religion; and art, culture, recreation, and sport. Perhaps their aspirations are more idealistic at this age. In reality, 30-year-olds are more likely to work in occupations such as management; business, finance, and administration; sales and service; trades, transport, and equipment operators and related; occupations unique to a primary industry; and occupations unique to processing, manufacturing, and utilities. By age 17, the distribution of intended occupations begins to look more like the actual distribution of occupations among 30-year-olds, but a large divide persists nonetheless. Given the nature of occupations involved, the gap between aspirations and realizations may be explained by unfulfilled aspirations to complete university. As noted in the introduction, we already know a considerable 
amount about the process underlying university attendance patterns. One potential factor that we know nothing about is the possible role of knowing what it takes to achieve one's career goals.

Students' knowledge of the educational requirements for their intended careers is shown in Table 1. Again, all youth who answered the question on career aspiration are included in the table. The results are broken down by level required (according to HRSDC), which is shown in the columns. Here, there are three categories: university degree (skill level A), usually a non-university post-secondary certificate (skill level B), and no more than a high school diploma (skill levels $\mathrm{C}$ and D). Our focus here is on skill level A. At age 15, there are 5,230 youth in the sample who aspired to a job requiring a university degree. The sample of their 17-year-old counterparts is 4,851.

At age 15, about 3 out of 4 students (77.8\%), who aspire to a job requiring a university degree, know that a degree is required. About one out of $8(12.1 \%)$ believe that no more than a high school diploma is required, or simply don't know. By age 17, knowledge is more closely aligned with the HRSDC baseline, with $83.8 \%$ believing a university degree is required. One possible reason for the increase is a compositional shift over time in the type of students wanting a job requiring a university degree. However, when individuals who want a job requiring a university degree in both periods are selected, the proportion of students who know that a degree is required also rises (from $81.5 \%$ to $86.9 \%$ ).

Table 1

\section{Distribution of student perceptions of education required by education required}

\begin{tabular}{|c|c|c|c|c|c|}
\hline \multirow[t]{2}{*}{ Education required } & \multicolumn{5}{|c|}{$\begin{array}{l}\text { Percentage distribution of student perceptions of education } \\
\text { required }\end{array}$} \\
\hline & $\begin{array}{l}\text { Don't } \\
\text { know }\end{array}$ & $\begin{array}{c}\text { No more than } \\
\text { a high school } \\
\text { diploma }\end{array}$ & $\begin{array}{c}\text { NUPS } \\
\text { certificate }\end{array}$ & $\begin{array}{l}\text { University } \\
\text { degree }\end{array}$ & Total \\
\hline \multicolumn{6}{|l|}{ 15-year-olds } \\
\hline No more than a high school diploma & 6.5 & 28.2 & 41.2 & 24.1 & 100.0 \\
\hline Usually NUPS certificate & 8.0 & 14.2 & 44.9 & 33.0 & 100.0 \\
\hline University degree & 7.0 & 5.1 & 10.2 & 77.8 & 100.0 \\
\hline \multicolumn{6}{|l|}{ 17-year-olds } \\
\hline No more than a high school diploma & 0.0 & 17.4 & 59.3 & 23.2 & 100.0 \\
\hline Usually NUPS certificate & 0.1 & 11.3 & 68.9 & 19.7 & 100.0 \\
\hline University degree & 0.2 & 1.9 & 14.1 & 83.8 & 100.0 \\
\hline
\end{tabular}

Note. NUPS=non-university postsecondary.

Source: Youth in Transition Survey, Cohort A.

The increase in the percentage of students who are aware of the education levels required to reach their job aspirations may result from many sources, such as teachers, guidance counsellors, parents, friends, or a personal initiative. The potential role (in a correlative sense), of student characteristics, parental influences, and schooling will be assessed more carefully below.

Table 1 also contains information on students who aspire to a job requiring less than a university degree. It is interesting to note that a non-negligible portion of 
students actually believe that a university degree is required. For example, 23.2\% of 17-year-olds who want a job requiring no more than a high school diploma believe that a university degree is required to meet their goal. Thus, misinformation appears to work in both directions.

In Table 2, I begin focusing exclusively on students who want a job requiring a university degree. The percentage of students who know that a university degree is required is shown by intended occupation. The occupations are grouped into threedigit S0C91 codes, which are somewhat more detailed than the one-digit codes used in Figure 1. Note that certain specific occupations within these three-digit codes do not require a university degree; however, these occupations are excluded here since only students who aspire to occupations requiring a university degree are included.

Table 2

Percentage of students who know that a university degree is required for their intended occupation by intended occupation

Intended occupation

Percentage of students who know that a university degree is required

Architects, Urban Planners and Land Surveyors

\begin{tabular}{|c|c|}
\hline 15-year-olds & 17-year-olds \\
\hline 68.5 & 80.7 \\
\hline 77.5 & 75.5 \\
\hline-- & -- \\
\hline 33.9 & 53.6 \\
\hline 80.1 & 79.1 \\
\hline 85.6 & 89.9 \\
\hline -- & -- \\
\hline 90.5 & 97.9 \\
\hline -- & -- \\
\hline 84.5 & 85.4 \\
\hline 63.7 & 54.6 \\
\hline 67.5 & 74.2 \\
\hline 83.9 & 93.5 \\
\hline 85.5 & 94.7 \\
\hline 91.8 & 95.8 \\
\hline 92.4 & 96.9 \\
\hline 87.8 & 95.5 \\
\hline 77.1 & 84.0 \\
\hline 87.9 & 96.0 \\
\hline 85.6 & 94.1 \\
\hline-- & 94.7 \\
\hline 66.8 & 81.2 \\
\hline
\end{tabular}

Auditors, Accountants and Investment Professionals

College and Other Vocational Instructors

Creative and Performing Artists

Engineers: Civil, Mechanical, Electrical, Chemical

Engineers: Other

Human Resources and Business Service Professionals

Judges, Lawyers and Quebec Notaries

Librarians, Archivists, Conservators and Curators

Life Science Professionals

Mathematicians, Systems Analysts and Computer Programmers

Nurse Supervisors and Registered Nurses

Optometrists, Chiropractors and Other Health Diagnosing and

Treating Professionals

Pharmacists, Dietitians and Nutritionists

Physical Science Professionals

Physicians, Dentists and Veterinarians

Policy and Program Officers, Researchers and Consultants

Psychologists, Social Workers, Counsellors, Clergy and Probation Officers

Secondary and Elementary School Teachers and Counsellors

Therapy and Assessment Professionals

University Professors and Assistants

Writing, Translating and Public Relations Professionals

66.8

81.2

Note. Only students who indicated wanting a job requiring a university degree are included in the sample. “--" indicates sample size below 30.

Source: Youth in Transition Survey, Cohort A. 
While most occupation-specific results are close to the broader results reported in Table 1, there are a few exceptions. For example, fewer than two out of three students who intend on working in a job classified under "mathematicians, systems analysts, and computer programmers" know that a university degree is required. Students who aspire to become nurse supervisors and registered nurses or creative and performing artists, are also less likely than other students to know that a university degree is required. On the other hand, the educational requirements of many other occupations are well known among students, including: physical science professionals; physicians, dentists, and veterinarians; pharmacists, dieticians, and nutritionists; therapy and assessment professionals; judges, lawyers, and Quebec notaries; secondary and elementary school teachers and counsellors; and policy and program officers, researchers, and consultants.

In Table 3, the factors associated with knowledge of educational requirements are presented. Once again, only students who aspire to a job requiring a university degree are included. The goal here is to model the probability of knowing that a university degree is required as a function of various individual and socioeconomic characteristics. The estimation approach is ordinary least squares (linear probability model). The coefficients are thus interpreted directly in probability terms (e.g. a coefficient of 0.8 represents an 80 percentage point difference in the probability of the outcome). ${ }^{2}$

The probability of knowing the educational requirement for one's intended job is positively associated with academic performance and parental background, including education, income, and immigrant status. The coefficients for parental background measures are larger at age 15 than at age 17. At age 15, there are no gender differences, while at age 17 , females are more likely than males to have correct knowledge. Finally, birth order and parental presence are not statistically significant factors.

In Table 4, the estimates of the relationship between years of schooling and student knowledge of job requirements (with a first-stage to instrument for the actual grade) are shown. Recall that this analysis is only possible in certain jurisdictions (Québec and Nova Scotia). Note also that only the main coefficients will be shown in the tables from now on. ${ }^{4}$ While the first-stage coefficients are highly significant (suggesting a strong instrumental variable), the second-stage estimates are actually negative, albeit not significant. This suggests no correlation between additional schooling and knowledge about educational requirements. Why might this be the case? Although this article does not (and can not) provide a clear answer to this question, some insights might be available in Bell and Bezanson (2006). They use a variety of national and provincial surveys to investigate use of career development services, and conclude that most young Canadians do not have adequate access to these services. It is not clear from their study whether youth are not using career development services because they do not wish to do so, or because they are simply not available.

In Table 5, I show the results of regressing various levels of educational attainment (either completed or attended) on the knowledge of educational requirements at either age 15 or 17, controlling for the characteristics mentioned so far. Recall that only students who aspire to a job requiring a university degree are included in the sample at this point. Furthermore, I return to the main sample (i.e. all regions) from this point onward. The results suggest that students who know at age 15 that a university degree is required for the career they are interested in, have a 15.5 percentage point higher university enrolment rate by age 21 . Repeating the analysis for 17-year-olds, the figure al- 
Table 3

Impact of student characteristics and strategies on the probability of knowing a university degree is required

15-year-olds 17-year-olds

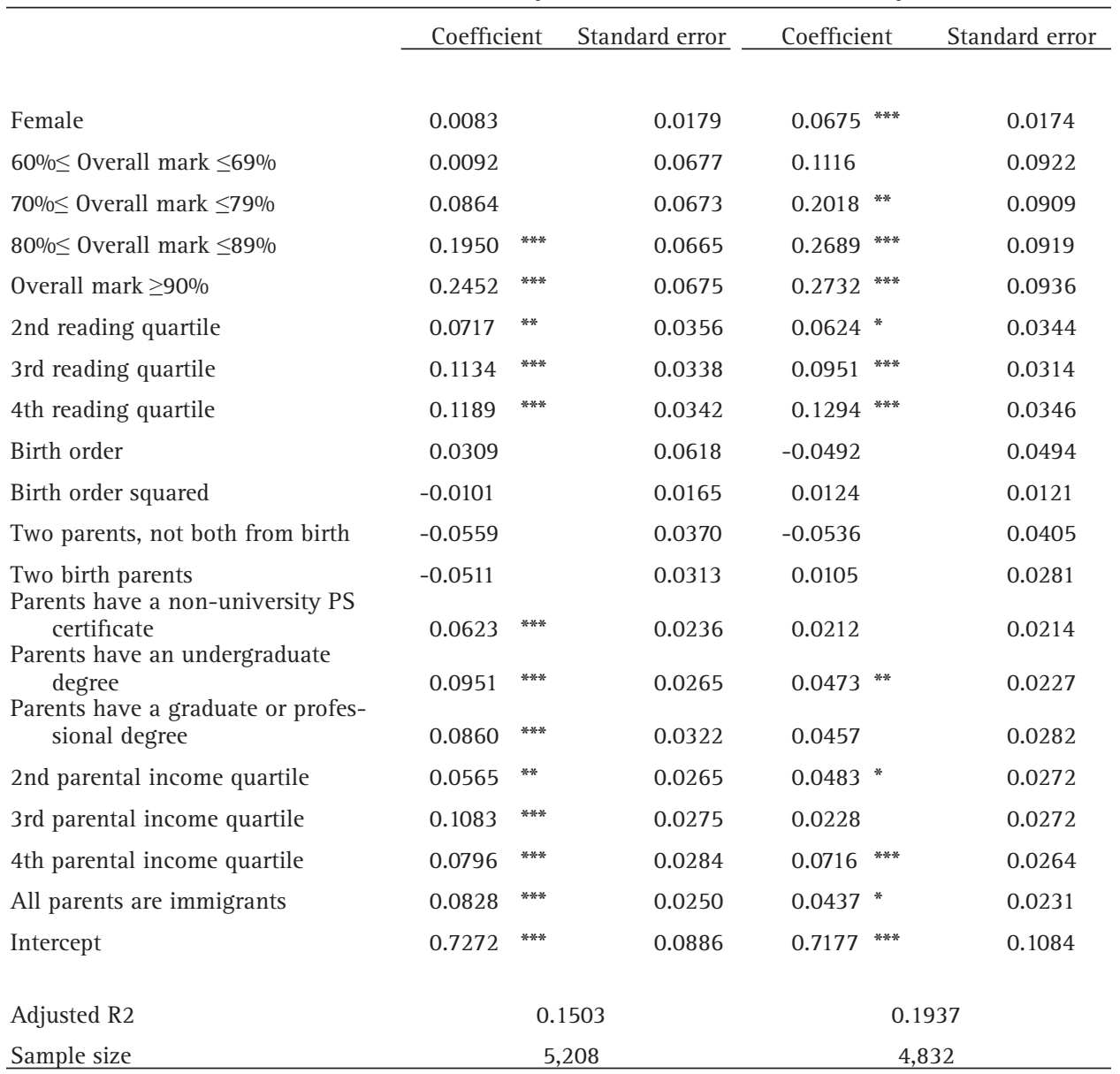

Note. ${ }^{* * *}=$ significant at $1 \%$; ${ }^{* *}=$ significant at $5 \%$; ${ }^{*}=$ significant at $10 \%$. Only students who indicated at age 15 or age 17 wanting a job requiring a university degree are included in the sample. The model is estimated by ordinary least squares and school fixed effects are included.

Source: Youth in Transition Survey, Cohort A.

most doubles (to a 29.1 percentage point advantage). These numbers are comparable to several well-known correlates of university attendance, such as sex, overall marks, and parental education. See Frenette (2007), for results pertaining to those correlations.

Perhaps it is not surprising that students who know that a university degree is required for their intended career are more likely to attend university. But does knowing earlier matter? Earlier knowledge may help students prepare accordingly for university application. Given the structure of the YITS data, the distinction here is between ages 15 and 17. In Table 6, I show results from a regression of university attendance on the pathways of knowledge, between the ages of 15 and 17 among students who aspired to 
Table 4

Impact of an additional year of schooling on the probability of knowing a university degree is required

\begin{tabular}{|c|c|c|c|c|}
\hline & \multicolumn{2}{|c|}{ 15-year-old sample } & \multicolumn{2}{|c|}{ 17-year-old sample } \\
\hline & Coefficient & $\begin{array}{l}\text { Standard } \\
\text { error }\end{array}$ & Coefficient & $\begin{array}{l}\text { Standard } \\
\text { error }\end{array}$ \\
\hline $\begin{array}{l}\text { First stage: Impact of being born before the } \\
\text { school entry cut-off on school grade }\end{array}$ & $0.5598^{* * * *}$ & 0.0673 & $0.3985^{* * * *}$ & 0.0808 \\
\hline $\begin{array}{l}\text { Second stage: Impact of one additional school } \\
\text { grade on knowing that a university degree } \\
\text { is required for intended career }\end{array}$ & -0.1245 & 0.0950 & -0.1731 & 0.1550 \\
\hline
\end{tabular}

Note. ${ }^{* * * *}=$ significant at $1 \% ;{ }^{* * *}=$ significant at $5 \% ;{ }^{*}=$ significant at $10 \%$. Only school grade students from Nova Scotia and Québec (15-year-olds) or Nova Scotia (17-year-olds) who indicated wanting a job requiring a university degree are included in the samples. This includes 1,317 15-year-olds and 484 17-year-olds. All models are estimated by ordinary least squares and include the covariates listed in

Table 2 (except the strategy variables), as well as school fixed effects and age (in years).

Source: Youth in Transition Survey, Cohort A.

\section{Table 5}

Impact of student perceptions of education required on educational outcomes

\begin{tabular}{|c|c|c|c|c|c|c|c|c|c|}
\hline \multirow[b]{3}{*}{$\begin{array}{l}\text { Knows a university degree } \\
\text { is required (age 15) }\end{array}$} & \multicolumn{3}{|c|}{ Completed high school } & \multicolumn{3}{|c|}{ Attended postsecondary } & \multicolumn{3}{|c|}{ Attended university } \\
\hline & \multicolumn{2}{|c|}{ Coefficient } & \multirow{2}{*}{$\begin{array}{c}\begin{array}{c}\text { Standard } \\
\text { error }\end{array} \\
0.0120\end{array}$} & \multicolumn{2}{|c|}{ Coefficient } & \multirow{2}{*}{$\begin{array}{c}\begin{array}{c}\text { Standard } \\
\text { error }\end{array} \\
0.0213\end{array}$} & \multicolumn{2}{|c|}{ Coefficient } & \multirow{2}{*}{$\begin{array}{c}\begin{array}{c}\text { Standard } \\
\text { error }\end{array} \\
0.0237\end{array}$} \\
\hline & -0.0069 & & & 0.0457 & $* *$ & & 0.1547 & $* * * *$ & \\
\hline $\begin{array}{c}\text { Knows a university degree } \\
\text { is required (age 17) }\end{array}$ & 0.0481 & ** & 0.0192 & 0.1339 & $* * * *$ & 0.0285 & 0.2912 & $* * * *$ & 0.0280 \\
\hline Difference & 0.0549 & ** & 0.0227 & 0.0882 & $* *$ & 0.0356 & 0.1365 & $* * * *$ & 0.0367 \\
\hline
\end{tabular}

Note. ${ }^{* * *}=$ significant at $1 \% ;{ }^{* *}=$ significant at $5 \% ;{ }^{*}=$ significant at $10 \%$. Only students who indicated at age 15 or age 17 wanting a job requiring a university degree are included in the samples. This includes 5,208 15-year-olds and 4,832 17-year-olds. All models are estimated by ordinary least squares and include the covariates listed in Table 2 (except the strategy variables), as well as school fixed effects.

Source: Youth in Transition Survey, Cohort A.

\section{Table 6}

Impact of trajectory of student perceptions of education required on university attendance

\begin{tabular}{llllc} 
Student perceptions at age 15 & Student perceptions at age 17 & Coefficient & & Standard error \\
\hline No university degree & No university degree & -0.3704 & $* * *$ & 0.0435 \\
No university degree & University degree & -0.1690 & $* * * *$ & 0.0380 \\
University degree & No university degree & -0.3198 & $* * *$ & 0.0479 \\
University degree & University degree & Omitted & & \\
\hline
\end{tabular}

Note. ${ }^{* * *}=$ significant at $1 \% ;{ }^{* *}=$ significant at $5 \% ;{ }^{*}=$ significant at $10 \%$. Only students who indicated wanting a job requiring a university degree at both age 15 and age 17 are included in the sample. This includes 3,348 youth. The model is estimated by ordinary least squares and includes the covariates listed in Table 2, as well as school fixed effects. Note that school marks at ages 15 and 17 are interacted.

Source: Youth in Transition Survey, Cohort A. 
a career requiring a university degree at both ages. Four distinct pathways are possible (two possible states - either knowing or not knowing that a university degree is required - in each period). The reference (omitted) category is "knowing that a university degree is required" in both periods.

Among students who, at age 17, knew that a university degree was required for their intended career, does it matter if they were aware of this earlier (at age 15)? The answer is yes: students who didn't know at age 15 were 16.9 percentage points less likely to attend university than those who knew at both points in time, which is statistically significant at $1 \%$.

Testing the robustness of this result is warranted. These results appear in Table 7. First, recall from the methodology section that an alternative definition of educational requirements is used. In this instance, if students believe that any type of post-secondary certificate is required, then they are deemed to know the level required (even if the HRSDC standard is a university degree). This measure is adopted because it is possible that not all jobs in the same occupational classification require the same level of education. In the top portion of the table, the results indicate that failure to know the requirements (as defined here), is related to a lower probability of both university and post-secondary attendance in general. The estimated magnitudes are 11.1 and 13.1 percentage points, respectively. In both cases, they are statistically significant at $1 \%$.

Second, the causal nature of this relationship is questionable given the lack of an identification strategy, and the possibility that students who more strongly aspire to their intended career are more likely to inform themselves about the educational requirements to achieve their goal. However, respondents in YITS are asked, "How certain are you that you will eventually have this career or work?" The possible answers are: very certain, fairly certain, fairly uncertain, and very uncertain. When dummy variables corresponding to these categories are added to the models, the results are largely unchanged (as suggested by the bottom of Table 7). Once again, the coefficients are statistically significant at $1 \%$.

\section{CONCLUSION}

This article has examined high school students' knowledge of educational requirements for their intended career at age 30, as well as the role of this knowledge in shaping future educational decisions. The article adds to a large body of literature on factors associated with higher education, which has largely focused on factors such as academic performance, parental income, distance to school, sex, parental education, and immigrant status. To date, research has not investigated student perceptions of educational requirements of future (desired) careers, either in Canada or the rest of the world.

The results suggest that about three out of four students intending to work in a job requiring a university degree are aware of the education necessary, while one in four underestimates the level of education required - about half of them stating that only a high school diploma is required. Evidence suggests that knowledge of educational requirements is related to academic performance and socio-economic background, and less so to schooling (the latter evidence drawn from two provinces). Differences by intended occupation are quite small. Moreover, students who know that a university degree is required are more likely to attend university, even after accounting for differences in academic performance, sex, and socioeconomic background. In fact, the 
Table 7

Impact of trajectory of student perceptions of education required on university and postsecondary attendance

\begin{tabular}{|c|c|c|c|c|c|c|c|}
\hline \multirow{2}{*}{$\begin{array}{l}\text { Student perceptions at } \\
\quad \text { age } 15\end{array}$} & \multirow[b]{2}{*}{$\begin{array}{l}\text { Student perceptions at } \\
\text { age } 17\end{array}$} & \multicolumn{3}{|c|}{$\begin{array}{l}\text { University } \\
\text { attendance }\end{array}$} & \multicolumn{3}{|c|}{$\begin{array}{c}\text { Postsecondary } \\
\text { attendance }\end{array}$} \\
\hline & & Coefficie & ent & $\begin{array}{l}\text { Standard } \\
\text { error }\end{array}$ & Coefficie & & $\begin{array}{l}\text { Standard } \\
\text { error }\end{array}$ \\
\hline $\begin{array}{l}\text { Don't know or high } \\
\text { school or less }\end{array}$ & $\begin{array}{l}\text { Don't know or high } \\
\text { school or less }\end{array}$ & -0.1502 & & 0.1350 & -0.1027 & & 0.1454 \\
\hline $\begin{array}{l}\text { Don't know or high } \\
\text { school or less }\end{array}$ & $\begin{array}{l}\text { Postsecondary } \\
\text { certificate }\end{array}$ & -0.1114 & *** & 0.0409 & -0.1306 & $* * *$ & 0.0354 \\
\hline $\begin{array}{l}\text { Postsecondary certifi- } \\
\text { cate }\end{array}$ & $\begin{array}{l}\text { Don't know or high } \\
\text { school or less }\end{array}$ & -0.0997 & & 0.1062 & -0.0825 & & 0.0846 \\
\hline $\begin{array}{l}\text { Postsecondary certifi- } \\
\text { cate }\end{array}$ & $\begin{array}{l}\text { Postsecondary } \\
\text { certificate }\end{array}$ & Omitted & & & Omitted & & \\
\hline \multicolumn{8}{|c|}{ Adding certainty of working in intended career to models... } \\
\hline & & \multicolumn{3}{|c|}{$\begin{array}{c}\text { University } \\
\text { attendance }\end{array}$} & \multicolumn{3}{|c|}{$\begin{array}{c}\text { Postsecondary } \\
\text { attendance }\end{array}$} \\
\hline $\begin{array}{l}\text { Student perceptions at } \\
\text { age } 15\end{array}$ & $\begin{array}{l}\text { Student perceptions at } \\
\text { age } 17\end{array}$ & Coefficie & ent & $\begin{array}{l}\text { Standard } \\
\text { error }\end{array}$ & Coefficie & & $\begin{array}{l}\text { Standard } \\
\text { error }\end{array}$ \\
\hline $\begin{array}{l}\text { Don't know or high } \\
\text { school or less }\end{array}$ & $\begin{array}{l}\text { Don't know or high } \\
\text { school or less }\end{array}$ & -0.1686 & & 0.1444 & -0.1163 & & 0.1479 \\
\hline $\begin{array}{l}\text { Don't know or high } \\
\text { school or less }\end{array}$ & $\begin{array}{l}\text { Postsecondary } \\
\text { certificate }\end{array}$ & -0.0963 & $* *$ & 0.0383 & -0.1406 & $* * *$ & 0.0369 \\
\hline $\begin{array}{l}\text { Postsecondary } \\
\text { certificate }\end{array}$ & $\begin{array}{l}\text { Don't know or high } \\
\text { school or less }\end{array}$ & -0.0884 & & 0.1012 & -0.0843 & & 0.0827 \\
\hline $\begin{array}{r}\text { Postsecondary } \\
\text { certificate }\end{array}$ & $\begin{array}{r}\text { Postsecondary } \\
\text { certificate }\end{array}$ & Omitted & & & Omitted & & \\
\hline
\end{tabular}

Note. ${ }^{* * *}=$ significant at $1 \% ;{ }^{* *}=$ significant at $5 \% ;{ }^{*}=$ significant at $10 \%$. Only students who indicated wanting a job requiring a university degree at both age 15 and age 17 are included in the sample. This includes $3,348(3,298)$ youth in the models without (with) the certainty of working in intended career. The model is estimated by ordinary least squares and includes the covariates listed in Table 2 , as well as school fixed effects. Note that school marks at ages 15 and 17 are interacted, as are certainty of working in intended career at ages 15 and 17.

Source: Youth in Transition Survey, Cohort A.

knowledge of educational requirements is as strongly related to university attendance as other well-documented correlates such as sex, academic performance, and parental education. Thus, the paper has identified a new factor in student choice theory: knowledge of educational requirements for anticipated careers. A useful avenue for future work would be to develop a theoretical framework encompassing intended careers, information on educational requirements, and chosen level of education. Finally, higher university attendance rates are observed when students learn earlier (rather than later), that a university degree is required for their intended job.

What are the implications of the results for higher education policy? If the results are to be believed (in a causal sense), then a relatively simple approach to raising educational attainment has been identified (i.e. ensuring that school children are aware of the educational requirements for their anticipated career). This intervention is also likely to be less expensive than large scale grants offered to students in need, although considerable time and effort may still be required to ensure that students have acquired 
the requisite knowledge. Moreover, intervening earlier may be more effective as students have time to adapt to the new information.

That being said, all of this depends on the original notion that information has a causal impact on student behaviour. While the results of this article are suggestive, they are far from being definitive. At best, they raise the possibility of a causal relationship. To be sure, more work is needed in this nascent area. To this end, a carefully designed social experiment, where treatment and control groups are randomly assigned would seem promising.

\section{REFERENCES}

Andres, L., \& Looker, E. D. (2001). Rurality and capital: Educational expectations and attainment of rural, urban/rural and metropolitan youth. Canadian Journal of Higher Education, 31(2), 1-46.

Bell, D., \& Bezanson, L. (2006). Career development services for Canadian youth: Access, adequacy and accountability. Pathways to the Labour Market Series, No. 1. Ottawa: Canadian Policy Research Networks and Canadian Career Development Foundation.

Christofides, L. N., Hoy, L., \& Yang, L. (2006). The gender imbalance in participation in Canadian universities (1977-2003). University of Guelph, Department of Economics Working Paper 2006-10. Guelph: University of Guelph.

Currie, S., Hutchison, J., Ford, R., Kwakye, I., \& Tattrie, D. (2007). Future To Discover pilot project: Early implementation report. Ottawa: Social Research and Demonstration Corporation and Canada Millennium Scholarship Foundation.

Demnati, A., \& Rao, J. N. K. (2004). Linearization variance estimators for survey data (with discussion). Survey Methodology, 30, 17-34.

Finnie, R., \& Mueller, R. (2008). Access to post-secondary education in Canada among first and second generation Canadian immigrants: Raw differences and some of the underlying factors. Mimeo.

Finnie, R., Sweetman, A., \& Lascelles, E. (2005). Who goes? The direct and indirect effects of family background on access to post-secondary education. Analytical Studies Branch Research Paper Series. Catalogue no. 11F0019MIE2005237. Ottawa: Statistics Canada.

Frenette, M. (2004). Access to college and university: Does distance to school matter? Canadian Public Policy, 30(4), 427-443.

Frenette, M. (2006). Too far to go on? Distance to school and university participation. Education Economics, 14(1), 31-58.

Frenette, M. (2007). Why are youth from lower-income families less likely to attend university? Evidence from academic abilities, parental influences, and financial constraints. Analytical Studies Branch Research Paper Series. Catalogue no. 11F0019MIE2007295. Ottawa: Statistics Canada.

Frenette, M. (2008a). University access amid tuition fee deregulation: Evidence from Ontario professional programs. Canadian Public Policy, 34(1), 89-110.

Frenette, M. (2008b). The returns to schooling on academic performance: Evidence from large samples around school entry cut-off dates. Analytical Studies Branch Research Paper Series. Catalogue no. 11F0019MIE2008317. Ottawa: Statistics Canada. 
Frenette, M. (2009). Do universities benefit local youth? Evidence from the creation of new universities. Economics of Education Review, 28(3), 318-328.

Frenette, M., \& Zeman, K. (2007). Why are most university students women? Evidence based on academic performance, study habits and parental influences. Analytical Studies Branch Research Paper Series. Catalogue no. 11F0019MIE2007303. 0ttawa: Statistics Canada.

Galarneau, D., \& Morissette, R. (2004). "Immigrants: settling for less?" Perspectives on Labour and Income, 5(6), 5-16.

Usher, A. (2005). A little knowledge is a dangerous thing: How perceptions of costs and benefits affect access to education. Toronto, Canada: Educational Policy Institute.

\section{APPENDIX}

Appendix 1

Sample statistics of covariates used in the analysis

\begin{tabular}{|c|c|c|c|c|}
\hline & \multicolumn{2}{|c|}{ 15-year-olds } & \multicolumn{2}{|c|}{ 17-year-olds } \\
\hline & Mean & $\begin{array}{l}\text { Standard } \\
\text { deviation }\end{array}$ & Mean & $\begin{array}{l}\text { Standard } \\
\text { deviation }\end{array}$ \\
\hline Female & 0.5786 & 2.0407 & 0.5708 & 2.0062 \\
\hline Overall mark <60\% & 0.0366 & 0.7761 & 0.0200 & 0.5681 \\
\hline $60 \% \leq$ Overall mark $\leq 69 \%$ & 0.1216 & 1.3508 & 0.1001 & 1.2164 \\
\hline $70 \% \leq$ Overall mark $\leq 79 \%$ & 0.3095 & 1.9105 & 0.3672 & 1.9538 \\
\hline $80 \% \leq$ Overall mark $\leq 89 \%$ & 0.4096 & 2.0323 & 0.4075 & 1.9916 \\
\hline Overall mark $\geq 90 \%$ & 0.1227 & 1.3558 & 0.1052 & 1.2433 \\
\hline 1st reading quartile & 0.1590 & 1.5113 & 0.1678 & 1.5145 \\
\hline 2 nd reading quartile & 0.2213 & 1.7156 & 0.2282 & 1.7011 \\
\hline 3 rd reading quartile & 0.2920 & 1.8791 & 0.2730 & 1.8057 \\
\hline 4 th reading quartile & 0.3277 & 1.9397 & 0.3310 & 1.9073 \\
\hline Birth order & 1.4982 & 2.8189 & 1.5022 & 2.7830 \\
\hline Lone parent & 0.1295 & 1.3875 & 0.1321 & 1.3722 \\
\hline Two parents, not both from birth & 0.1134 & 1.3104 & 0.1127 & 1.2817 \\
\hline Two birth parents & 0.7571 & 1.7722 & 0.7552 & 1.7426 \\
\hline Parents have high school or less & 0.2878 & 1.8710 & 0.2879 & 1.8351 \\
\hline Parents have a non-university PS certificate & 0.3630 & 1.9873 & 0.3565 & 1.9413 \\
\hline Parents have an undergraduate degree & 0.2231 & 1.7205 & 0.2250 & 1.6926 \\
\hline Parents have a graduate or professional degree & 0.1261 & 1.3721 & 0.1306 & 1.3657 \\
\hline 1st parental income quartile & 0.2375 & 1.7588 & 0.2433 & 1.7391 \\
\hline 2nd parental income quartile & 0.2325 & 1.7458 & 0.2341 & 1.7162 \\
\hline 3rd parental income quartile & 0.2488 & 1.7866 & 0.2493 & 1.7534 \\
\hline 4th parental income quartile & 0.2812 & 1.8580 & 0.2733 & 1.8063 \\
\hline All parents are immigrants & 0.2147 & 1.6970 & 0.2146 & 1.6639 \\
\hline
\end{tabular}

Note. Only students who indicated at age 15 or age 17 wanting a job requiring a university degree are included in the samples.

Source: Youth in Transition Survey, Cohort A. 


\section{CONTACT INFORMATION}

Marc Frenette

Social Research and Demonstration Corporation

55 Murray Street, Suite 400, Ottawa K1N 5M3

Telephone number: 613-237-6778

Facsimile number: 613-237-5045

Email: mfrenette@srdc.org

Marc Frenette is a researcher with the Social Research and Demonstration Corporation (SRDC), where his main focus is on completing two major demonstration projects on access to postsecondary studies (Future to Discover and BC AVID). He also acts as a core research member of the Returns to Adult Education Research Program, a major collaboration between SRDC and the Canadian Labour Market and Skills Researcher Network (CLSRN). Before joining SRDC, Marc was a research economist with the Business and Labour Market Analysis Division at Statistics Canada for several years. He has published several research papers in Canadian and international scientific journals, produced many government research documents, and written chapters for various policy-oriented academic books. He is co-editor of a book entitled "Pursuing Higher Education in Canada: Economic, Social, and Policy Dimensions". Marc holds a Ph.D. in Economics from the University of Nottingham.

\section{ACKNOWLEDGEMENTS}

This research began while I was employed at Statistics Canada. An early version of the paper is available at http://www.statcan.gc.ca/pub/11f0019m/11f0019m2009320eng.pdf. The final article benefited substantially from comments by many people, including: Garnett Picot, René Morissette, and Grant Schellenberg of Statistics Canada, individuals present at talks I gave at the Policy Research Initiative in Ottawa (December, 2008) and the Canadian Economics Association meetings in Québec City (May, 2010), as well as three anonymous referees.

\section{NOTES}

1. Given this complex survey design, variance measures based on the assumption of a simple random sample are incorrect. To address this issue, I estimate variance measures using a Taylor linear approximation (Demnati \& Rao, 2004).

2. Note that results from logit and probit models are similar and are available upon request.

3. Briefly, the approach is called instrumental variable (or two-stage least squares) regression. In the first stage, the actual grade is regressed on the assigned grade and other covariates believed to determine student perceptions. In the second stage, student perceptions are regressed on these same covariates plus the predicted grade generated from the first stage.

4. Full model results are available upon request. 